\title{
Kitörés a múlt homályából
}

\section{Gondolatok Kemény János és Nagy Tamás Magyar katonák Dél-Vietnámban 1973-1975 címú monográfiájáról}

Egy átlagos európai vagy észak-amerikai embernek mindmáig a vietnámi háborúról jut eszébe a legtöbb dolog Délkelet-Ázsia 20. századi történelmének epizódjai közül. Persze nagy szerepet játszik ebben az Amerikai Egyesült Államok filmiparának popkulturális hatása is, amely az 1970-es évek végétől ontotta azokat a hullámzó színvonalú opusokat, amelyek a vietnámi háború borzalmait történetmesélésük kontextusaként, háttereként, esetleg erkölcsi tanulságainak forrásaként ábrázolták - persze mindezt amerikai szemléletből kiindulva. Ennek nyomán a délkelet-ázsiai őserdőkben kúszó amerikai katonák tragikus hősökké nemesültek, míg a vietnámi oldal képviselői többnyire a név és személyiségjegyek nélküli (vagy kifejezetten bestiális vonásokkal ábrázolt) „rosszfiúk” szerepébe kerültek.

Nem érdemes vitatni, hogy - hasonlóan más nyugati társadalmakhoz - az ekkortájt, illetve azóta született magyar nemzedékek témával kapcsolatos gondolkodására is ezek a fogyasztói termékek gyakorolták a legnagyobb hatást. Igaz volt mindez annak ellenére, hogy az idősebbek számára a korabeli magyar hírszolgáltatásból jól megismerhető volt a konfliktus észak-vietnámi narratívája is. A magyarországi Y generáció számára a vietnámi kérdés mégis erősen „szórakoztatóipari” tálalásban jelent meg, noha a két nép jó kapcsolata általában ismert volt mindenki elött, aki csak kis érdeklődést mutatott Magyarország külkapcsolatai iránt. Jócskán van tehát mit korrigálni annak érdekében, hogy a múlt eseményeit kiegyensúlyozottabban ismerhessük meg. Szerencsére az elmúlt időszakban modern szemléletű alkotások megjelenésével már elkezdődött ez a munka.

Miközben a vietnámi háborúról általában sokan tudnak (vagy tudni vélnek) valamit, az teljesen feledésbe merült, hogy a konfliktus záró szakaszában a Magyar Néphadseregnek is jutott egy sajátos szerep. A Magyar Népköztársaság volt ugyanis az egyik azon négy állam közül, amely az 1973-as párizsi békeszerződés betartásának ellenőrzésére létrejött Nemzetközi Ellenőrző és Felügyelő Bizottságot (NEFB) alkotta. Kemény János politológus és Nagy Tamás hadtörténész 2020-ban, Magyar katonák Dél-Vietnámban 1973-1975 címen megjelent átfogó monográfiájukat éppen ennek a küldetésnek szentelik, amivel komoly hézagot sikerült betölteniük a 20. századi magyar had- és politikatörténettel foglalkozó könyvészetben. Fontos itt tisztázni, hogy a kötet nem a vietnámi háborúról magáról, hanem - címének megfelelően - a magyar katonák itteni szerepvállalásáról, mindennapjairól, feladataik végrehajtásának katonai és politikai összetevőiről szól. Magának a konfliktusnak az eseményei, illetve lényeges fordulópontjai természetesen említést kapnak, de csak mint az NEFB müködését alapvetően befolyásoló körülmények. Egyebekben a szó a magyar vonatkozású információké, ezeken belül is szigorúan a katonai tevékenység kerül górcső

Háda Béla a Nemzeti Közszolgálati Egyetem Eötvös József Kutatóközpont Stratégiai Védelmi Kutatóintézet tudományos munkatársa. E-mail: hada.bela@uni-nke.hu 
alá. Az ezzel párhuzamosan - illetve megelőzően - zajló diplomáciai munka jelentősége nem vitatható, és a jövőben érdemes lenne ezt is feldolgozni, a szerzők azonban szükebb kereteket adtak a vizsgálatuknak. Ezen belül viszont igen alapos kutatást folytattak, amelynek eredménye a magyar katonák dél-vietnámi ténykedésének aprólékos részletekbe menő feltárása lett.

A Magyar Néphadsereg vietnámi szerepvállalása már önmagában is érdekes, mérföldkőnek számító fejlemény volt. A II. világháborút követően első ízben került a magyar állam, illetve fegyveres erő olyan helyzetbe, hogy egy nagy figyelmet kapó többnemzeti vállalkozás formálisan egyenrangú résztvevőjeként segítse elő egy, a nemzetközi biztonság szempontjából is kiemelten fontosnak ítélt politikai folyamat sikerét. Egyúttal a dél-vietnámi misszió a békefenntartással rokonítható (gyakorlatilag tüzszüneti megfigyelő) tevékenység első próbája is volt a magyar fegyveres erők számára, amely mintegy 20 évvel később, a rendszerváltást követően kezd nagy karriert befutni, immár a Magyar Honvédség berkeiben.

Mielött rátérnék a tartalom ismertetésére, nem érdemes szó nélkül hagynom a kötet tetszetős kiállítását. Kemény János és Nagy Tamás könyvét igen jó minőségü, tartós papírra nyomtatták és gazdag képanyaggal egészítették ki, amelyben a korabeli fotóknak van döntő súlya. A kettő persze összefügg, a fényképfelvételeket megfelelő minőségben csak hasonló adottságú papíron lehet közreadni. Mindez azonban nem változtat az olvasó szempontjából fontos tényeken: a kötet méretéhez képest meglepően nehéz (zsebkönyvként nem hordható), ugyanakkor az ismeretterjesztő kiadványok megjelenését idézően színgazdag, egyúttal anyagában tartós fizikai megjelenést kapott. A 62. oldal térképe rendkívül fontos, a későbbi mondanivaló szempontjából is releváns információkat tartalmaz. Olvasás közben rendszeresen visszalapoztam rá. Talán megérte volna egy egész oldalas felbontásban közölni (esetleg az előzéklapon), aminek megfontolását javasolnám a szerzőknek müvük esetleges további kiadásainál. Utóbbira minden esély megvan, hiszen az igényes kivitelezés mellé roppant érdekes tartalom társul.

Áttekintő jelleggel annyit kell itt az olvasó figyelmébe ajánlanom, hogy a mü struktúráját tekintve két nagy részre osztható, amelyek további tematikus részekből épülnek fel.

Az első rész a vietnámi magyar misszió életét, valamint működésének helyi és nemzetközi körülményeit részletekbe menően tárgyaló, hagyományos történeti feldolgozás. Kronológiai szakaszolását a szerzők jó érzékkel az egyes váltások kiutaztatásához kapcsolták. Nagy erénye e történeti áttekintésnek, hogy döntően máshol nem publikált primer forrásokra, levéltári dokumentumokra támaszkodva készült el. Tekintetbe véve, hogy a témáról eddig nem jelent meg más, hasonlóan aprólékos részletekbe bocsátkozó tudományos írás, máshogy nem is lehetett elkészíteni egy ilyen terjedelmü kötetet. Ezt az áttekintést egészíti ki az NEFB tevékenységének regionális színtereit jelentő hét körzet leírása, amely szinte leltári pontossággal ábrázolja a magyar katonák helyi szolgálatteljesítésének tárgyi/ infrastrukturális körülményeit. A mai olvasó számára az utóbbiakból kirajzolódott kép leginkább azt sugallja, hogy voltak olyan szállások, amelyek nagyjából hozták egy korabeli 
SZOT-üdülő szobájának nívóját, míg mások leginkább bambuszkunyhó-kategóriába estek. A munkakörülmények tehát változatosak, de leginkább nehezek voltak.

A kötet második nagy egysége az összterjedelem mintegy harmadát kitevő függelék, amely lényegében a párizsi békeszerződés szövegéből, az NEFB kijelölt magyar tagjainak hírszerzési tevékenysége eredményeit ismertető fejezetből, egyes résztvevők visszaemlékezéseiből, egykori leveleiből, a váltások személyzetének névsorából, valamint a vietnámi háború következményeit illusztráló rövid adatsorból áll össze. Ha netán valaki korábbi olvasmányélményeire támaszkodva úgy döntene, hogy a függeléket felesleges időtöltés elolvasnia, ez esetben mindenképpen hibát követne el. Valójában a függelék szövegrészei számos olyan információt tartalmaznak, amelyek tágabb kontextusba illesztve a történeti feltáró részben is helyet kaphattak volna, mivel lényegesen árnyalják a magyar katonák dél-vietnámi tevékenységéről alkotható képet. Különösen ajánlanám az olvasó figyelmébe a 2. számú melléklet, valamint Botz László leveleinek tartalmát, amelyek a magyar hírszerzési tevékenységbe engednek bepillantást. Egyúttal a 2. függelék - a kötet egyéb idézett levéltári forrásaival egyetemben - azt is egyértelművé teszi, hogy a magyar katonák hivatalos és nem hivatalos dél-vietnámi tevékenysége (utóbbi alatt a hírszerzést értem) egyértelműen a két kommunista fél (Észak-Vietnám és a Dél-vietnámi Ideiglenes Forradalmi Kormány - DIFK) érdekeinek szem elött tartásával zajlott. Amikor tehát a kötet szerzői kifejtik, hogy a dél-vietnámi rezsim különböző szervei mennyire távolságtartóan, illetve ellenségesen viselkedtek a magyar delegáció tagjaival szemben, az egy objektív megállapítás a részükről. Itt azonban meg kell jegyeznem, hogy erre a saigoniaknak minden okuk meg is volt. Ez persze nem menti azt az esetet, amikor a háború végnapjaiban a déliek szinte élő pajzsként akarták használni a lengyel és magyar delegáció tagjait Tan Son Nhut légitámaszpontján, ám álszentség lenne értetlenkednünk ellenséges érzéseik felett.

Mint láthatjuk tehát, a kötetben helyet kap a levéltári források és szakirodalom alapján született tudományos interpretációk mellett az „oral history” is, szerkezetileg azonban jól elkülönítve egymástól. Ez véleményem szerint jó megoldás. Minthogy azonban a személyes visszaemlékezésekhez, levelekhez nem szeretnék szakmai kommentárt füzni, a továbbiakban a kötet első részének (a történeti feldolgozásnak) szentelnék figyelmet.

Be kell ismernem, hogy a könyvet olvasva eltünődtem: miként lehetne meghatározni a pontos müfaját. A (had)történeti munka adja magát, de van a szövegnek több olyan vonása is, amely inkább az emlékkötetek jellemzője. Egyszerübben szólva: mintha a szerzőknek a célja nemcsak az utókor hiteles tájékoztatása lett volna, hanem hogy az egykori résztvevők, illetve hozzátartozóik minél jobb érzéssel vegyék kezükbe a művet. Mindemellett a Magyar katonák Dél-Vietnámban 1973-1975 elkészítésében a történelemtudományi módszertan túlsúlya érvényesült, ezért a fentiek dacára nyugodtan tekinthetjük szakkönyvnek. Ám Kemény János és Nagy Tamás nem mindig viszonyul távolságtartóan az említésre kerülő eseményekhez. Több helyen az a benyomása az olvasónak, hogy a szerzők nem elégedettek azzal a hatással, amelyet a misszióban részt vevők erőfeszítései váltottak ki az itthoni közvélemény, esetleg a katonai, illetve külpolitikai szakterületen dolgozók körében. Minden bizonnyal az emlékállítás igénye inspirálta, hogy helyenként méltató gesztusokat tesznek 
a magyar NEFB-küldetés szervezésében és lebonyolításában részt vállaló magánszemélyek felé. Utóbbi manapság idegen a személyek semleges értékelését favorizáló történetírói hagyománytól. Önmagában azonban nem minősül hibának, legfeljebb a szakma szabályainak megfelelően kissé több bizonyítást is elbírt volna (például Köszegvári Tibor ezredes jó felkészültségének méltatása milyen igazolható tényeken nyugszik?²).

A szerzők érezhető szándéka tehát, hogy - legalább utólag - megadják a misszió résztvevőinek ezt az elismerést és megbecsülést, amely állásfoglalásuk szerint megilleti őket kötelességeik teljesitéséért az adott, rendkívül nehéz körülmények közepette. Talán éppen e célt szem előtt tartva, talán másért, de nem fejtik ki részletesebben, hogy a párizsi egyezmény betartásának ellenőrzésében való szerepvállalás egyik résztvevő ország képviselői számára sem volt hőstörténet - mert nem lehetett az. A könyv olvasásakor ezeket a tanulságokat gyakran a sorok közé tekintve kell meglelnünk, és számomra ez kifejezetten szórakoztató volt. E recenzióban azonban érdemes kiemelnünk néhány döntő jelentőségü dolgot az NEFB müködésének körülményeit illetően.

A levéltári forrásokból idézett szövegrészek több alkalommal érzékeltetik, de a szerzők egyértelmüen mégsem adnak hangot neki, hogy valójában egyik vietnámi fél sem gondolkodott jóhiszemüen a tüzszünet betartása és a békefolyamat továbbvitele tekintetében. Éppen ellenkezőleg: nem akartak békét, meg akarták nyerni a háborút. Az ehhez szükséges feltételek biztosításához azonban mind a két vietnámi oldalnak némi időre volt szüksége. Az NEFB összetétele éppen azért alakult úgy, ahogy, hogy mind a kommunista, mind a nyugatbarát felek szövetségesei helyet kaphassanak benne és az egyhangú állásfoglalásokra kötelezett szervezet ne gátolhassa erőfeszítéseiket. Különösen érdekes példával szolgál erre az a feljegyzés, amely a dél-vietnámi kommunista ellenkormány képviselöjének instrukcióját veszi figyelembe magyar részről a tekintetben, hogy miért is kell megakadályozni, hogy kivizsgálják az esetleges észak-vietnámi katonai jelenlétet déli területeken. A pártatlanság tehát fel sem merülhetett az NEFB-et alkotó nemzeti delegációk munkájában és ezzel mindenki tisztában volt. Arról már csak később szerezhettek tudomást, hogy a párizsi egyezmény aláírásakor már mozgásban voltak egyes észak-vietnámi erők, amelyeknek majd az 1975-ös invázióban jut szerep. A hanoi elvtársak tehát jól tudták, hogy a szocialista testvérországok katonái egy olyan tüzszünet ellenőrzésére érkeztek a térségbe, amely semmiképpen nem fog sokáig fennmaradni.

Egyúttal az NEFB összetétele a diszfunkcionalitás második rétegét is megteremtette. Minekután a bizottságot alkotó államok kormányai is alapvető gyanakvással viseltettek egymás iránt, az egységes fellépésnek és hatékony munkavégzésnek nem alakultak ki a feltételei. Mint ahogy a kötet is részletesen bemutatja, a négy nemzet képviselőinek egyeztetésein az energiákat zömmel a puszta működési feltételek biztosítása és a tevékenységük jogi hátterének értelmezése (egyáltalán müködésük legitimitásának kérdése) kötötte le. Az adott feltételek mellett tehát nem volt esély rá, hogy valóban tüzszünet jöjjön létre és maradjon fenn a harcoló felek között, illetve azt pártatlan és egységes ellenőrzés kísérje. A nyíltan deklarált, alapvető célkitűzés szempontjából e kölcsönös rosszhiszemüséggel és gyanakvással terhelt légkörben a felügyelőbizottsági tevékenységnek valójában kevés

2 Kemény János - Nagy Tamás: Magyar katonák Dél-Vietnámban 1973-1975. Budapest, Zrínyi, 2020. $22-23$. 
értelme volt. Kanada - az NEFB-ben szerepet vállaló egyetlen valóban demokratikus ország - képviselői hamar felmérték ezt és el is hagyták a testületet. A háború záró katonai szakaszának kibontakozása pedig még az optimistábbak számára is világossá tette, hogy a tüzszünet már elméletileg sem működik, így a felügyelete is okafogyottá vált.

Minderről természetesen a magyar delegáció tagjai nem tehetnek és egyéni munkájukat sem minősíti az a forgatókönyv, amely szerint a vietnámi konfliktus lezárult. Még csak befolyásolni sem volt esélyük a történteket, ráadásul utólag már nyilvánvaló, hogy a fegyveres konfliktus újbóli - az északiak által tervszerűen végrehajtott - kiéleződése akár áldozatokat is szedhetett volna közülük. A fent leírtak tehát nem a résztvevőkkel szemben fogalmaznak meg kritikát és nem kérdőjelezik meg a kötet mondanivalóját a katonai miszszió vietnámi tevékenységét illetően. Mégis e körülmények miatt vélem úgy, hogy a magyar NEFB-szerepvállalást nemigen lehetett sikertörténetként jellemezni, amelyhez a rendszerváltás után az is hozzátett egy új szempontot, hogy Magyarország éppen azzal a szuperhatalommal kívánta bizonyítani értékközösségét és megnyerni jóindulatát, amely érdekei ellen Vietnámban állást foglalt. Egyetértek ugyanakkor a szerzők azon, a konklúzióban megfogalmazott kritikájával, miszerint a magyar NEFB-tevékenység tapasztalatait és tanulságait a Néphadsereg (majd Honvédség) elmulasztotta szervezeti szinten feldolgozni, jóllehet, legalább ennek meg kellett volna történnie. A konklúzióban az is kimondatik, hogy az NEFB rendeltetésszerủ müködése végeredményben lehetetlen volt. Ez egy nagyon fontos gondolat, amely lényegében az egész missziós tevékenység legvelösebb tanulsága.

A mű értelmezéséhez fontosnak tartom arra is felhívni a figyelmet, hogy a leírt események kontextusát a dél-vietnámi társadalmi, politikai és biztonságpolitikai közeg alkotja. Amikor tehát a szerzők megemlítik, hogy a déli rezsim igyekezett elhallgattatni a médiában a kormánykritikus hangokat, vagy utalást tesznek a rendszer antidemokratikus müködési módjára, azzal nem azt akarják sugallni, hogy ezzel szemben Észak-Vietnámban sokszínű és kritikus médiavilág, valamint többpárti demokrácia létezett volna, csak rögzítik a tényeket. Hasonlóképpen, amikor a magyar misszió vezető személyiségeinek előzetes pályafutásáról olvasva mai szemmel nem éppen szimpatikus epizódokat találunk (például közreműködés az 1956-os forradalom leverésében), azzal a szerzők nem példaértékűnek nyilvánítják az ismertetett személyek tevékenységét, mindössze adatokkal szolgálnak szakmai és politikai szocializációjuk megértéséhez. Ugyanis - mint ahogy jelzik is a mü elején - a politikai megbízhatóság nagyon fontos volt a kiküldendő állomány tagjainak összeválogatásakor és ez a vezetőkre különösen igaz. Nem meglepő módon ez a megbízhatóság nem a forradalmi és antikommunista eszmékkel való azonosulást jelentette. Mindennek ellenére az NEFB magyar tagozata igyekezett jó kapcsolatokat kialakítani a többi féllel, ez azonban - ha nem is teljesen zökkenőktől mentesen - csak a rokon ideológiai rendszert képviselő vietnámi csoportokkal és a lengyelekkel sikerült. Mindez szintén nem a kint szolgáló magyar személyzet mulasztása volt, hanem a magasabb politikai viszonyok érvényesülését mutatta.

Azt sem érdemes figyelmen kívül hagyni, hogy a Magyar Népköztársaság - a magyar állam 20. századi történelmében először - annak a harcoló félnek az oldalán állt, amely végül megnyerte a háborút. Így a legkevésbé sem állíthatjuk, hogy Budapest kiállásának nem volt semmilyen ma is értékelhető haszna. Megerősítette Magyarország és Vietnám baráti 
kapcsolatait, amelyek a legstabilabb relációkká váltak és maradtak hazánk számára a délkelet-ázsiai térségben. E barátság túlélte a hidegháborút és a jelentős eltérések kialakulását a felek politikai struktúrái között. Sőt nyugodtan kimondhatjuk: ez az egyike a kevés pozitív örökségnek, amelyet az egyébként stratégiai zsákutcának bizonyult kommunista múlt hagyott ránk. A Magyar katonák Dél-Vietnámban 1973-1975 címü kötet pedig tisztességesen teljesíti vállalt feladatát és átfogó, részletes képet rajzol elénk a magyar NEFB-misszió életéröl és tevékenységéről. Mindezt pedig történettudományi szemszögből hiteles és jól dokumentált kutatás alapozza meg. Kemény János és Nagy Tamás művéből számos olyan dolgot megtudhat a mai olvasó, amelyet máshonnan soha. Például, hogy miként segítették a lengyelek - bizalmas információk átadásával is - a magyarok felkészülését, hogy miért nem Romániát jelölték a vietnámiak a bizottságba és miért inkább Magyarországot, vagy például hogy miként segített a CIA a szorult helyzetbe került magyar katonáknak a háború végnapjaiban.

Különös erénye továbbá, hogy hősei nem arctalan személyek. A szerzők gondot fordítottak arra, hogy beszerezzék és közreadják a kint szolgáló egyenruhás személyzet (katonák és belügyi alkalmazottak) névsorát, és a függelékben szereplő visszaemlékezések lehetöséget adnak az olvasónak, hogy bepillantson a résztvevők érzelemvilágába is. Szó szerint a múlt homályából hozza ismét fényre a magyar fegyveres erők dél-vietnámi szerepvállalásának történetét ez a kötet, roppant tanulságos és információkban gazdag olvasmányélményt nyújtva. Kemény János és Nagy Tamás könyvének ott a helye mindenki polcán, aki a jelenkori magyar hadtörténelemmel, illetve politikatörténettel foglalkozik, tegye ezt akár szakemberként, akár érdeklődő olvasóként.

A recenzió tárgyát képező mű: Kemény János - Nagy Tamás: Magyar katonák DélVietnámban 1973-1975. Budapest, Zrínyi, 2020. 